\title{
AlVAR AALTO I SPÅREN
}

\author{
Gösta Salén
}

Great ideologies are made up of life's little details, rise up out of the ground. Our senses convey to us the raw material on which our thinking is based. On the other hand, we have to see to it that the world of the senses is our servant and not the other way round.

Alvar Aalto, Culture and Technology, 1947

RESAN: Vintern 1965 kände jag mej, som jag antar en orm känner sig vid skinnbyte. Hade just slutat ett arbete och inte fätt något nytt - och visste inte riktigt vad jag skulle göra. Tog en paketresa till Helsingfors.

Ett minne spelade troligen in. 1938 som 16-åring, hade jag representerat Sverige i segling utanför Helsingfors och vi hade lidit ett svidande nederlag, som det heter i sportpressen. Utan eget förvållande, faktiskt, ty den svenska båten tålde helt enkelt inte den finska sjön! Att segla är nödvändigt! Javisst! Men för oss gällde 'att ösa är nödvändigt' - så båten inte skulle sjunka. Vi öste medan vi, sjödränkta och huttrande, såg hur vår finske motståndare, stolt som en svan seglade i mål på de grova sjöarna. Dag efter dag. Känslan av ångest och vanmakt växte $\mathrm{i}$ tonårssjälen. Sådana spår sitter i. Kanske var det ett dolt begär efter revansch som plötsligt fick mej att ge mig iväg ensam till den finska huvudstaden mitt i smällkalla vintern.

\section{SAMTALET}

Jag klarar inte av sysslolöst turistande, utan vill alltid ha något att göra, en praktisk uppgift, om än så liten. Tidskriften
Arkitektur hade bett mej skaffa bilder av Aaltos Västmanland-Dalarnas nationsbyggnad i Uppsala. Den ena av arkitektens två byggnader i Sverige; den andra är Sundh center i Avesta. Att hämta bilder i Finland av en svensk byggnad, kan verka som att gå över ån efter vatten. Nej, för Aalto hade ett komplett bildarkiv av det egna verket, för såväl privat som allmänt bruk som han helst ville skulle användas. På det sättet utövade han viss kontroll över hur hans byggnader presenterades i press och media.

Middagstid efter min sena ankomst till Helsingfors, tog jag mej därför ut till Aaltos ateljé, i Munknäs, stans västra utkant och $f$. ö. nära presidentens bostad - där jag upplystes om att Aaltos arkiv förvarades i Arkitekturmuseet, så jag åkte in till stan igen. Men på Arkitekturmuseet upplystes jag om att bilder endast erhölls med arkitektens personliga tillstånd, varför jag återvände till ateljén.

Det hade blivit sent och den kultiverade 
GÖSTA SALÉN

sekretererskan meddelade att alla tyvärr gått för dagen - men om jag hade tid att 'dröja', ville hon ändå se om hon kunde göra något för 'min herre'. Strax var hon tillbaka och i dörröppningen bakom henne stod en kort och rak person som jag kände igen som Alvar Aalto. Han höll högerarmen stelt efter sidan och visade med andra armen in i huset och sa kort, nästan konstaterande, 'Kom doktorn ska vi prata'.

Senare förstod jag, att han i princip kallade alla med akademisk anknytning för 'doktor'. De som var det blev nöjda, medan de som inte var det, dit jag räknades - troligen blev smickrade. Umgänget förenklades på det sättet. Han behövde inte bekymra sig om yrke, social ställning m. m. vilket - som jag senare förstod inte intresserade honom, åtminstone inte när det gällde ett samtal av det här slaget. Det enda han visste om mej, var det som sekretererskan sagt och det kan inte ha varit mycket. Han inbjöd en obekant person för han ville ha någon att prata med.

Vi kom in $\mathrm{i}$ kontorets kantin och min värd slog upp två glas sherry (eller var det whisky?) och så började utan vidare spisning ett samtal om allt mellan himmel och jord, som obrutet pågick i närmare tre timmar!

Inledningsvis uttryckte jag min beundran för den vita långsträckta villaarkitektur, som jag sett på utfärden. Hur fint de låga byggnaderna harmonierade med sandrevlarna och sundets vattenspegel. Och - det hade jag märkt - inget hus nådde upp över furornas toppar. Han lyssnade . noga och sa sedan sakta: "Jo, så borde det $\mathrm{i}$ alla fall vara."

Pendlade sedan över till Stockholm och frågade vilka funktionalistiska byggnads-

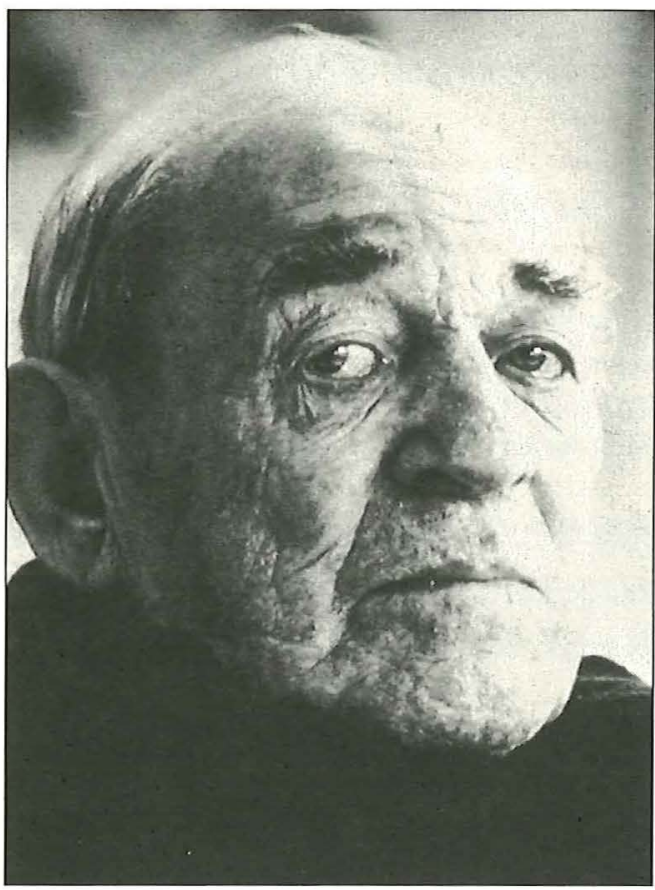

Porträtt av Alvar Aalto vid 76 airs alder. Foto Adam Woolfitt.

verk han satte högst och svaret kom prompt och i ett ord: «Broarna!» (med långt «o».) Årsta, Traneberg, Västerbron Stockholm har ju verkligen ett knippe vackra broar att bjuda på, som måste tilltala en renlärig finne. Men hade han undvikit frågan? Aalto kände ju sina funktionalistiska kolleger i Sverige, och var god vän med flera. Ville väl därför inte binda sig i någon riktning. Han satt tyst ett tag, så kom det eftertänksamt: "Men den svenska bostadsstandarden är mycket hög.» Och härmed fick han väl balans i frågan.

Övergick till mitt eget område, vandrande utställningar med konst och arkitektur och frågade en sak, som jag menade, men lät omöjlig när jag väl formulerat den: 
"Hur kommer det sig, arkitekt Aalto, att när jag presenterar en konstutställning först i Stockholm och sedan i Visby på Gotland, så upplever jag konstverken starkare på den senare orten än på den förra?» Han gav mig en prövande blick och svarade sedan, som om frågan både var självklar och väsentlig: «Det beror på att $\mathrm{i}$ Visby känner människorna varandra åtminstone till utseendet när de möts $\mathrm{i}$ lokalen, något som inte är fallet i Stockholm. Bra att ni valde Visby som exempel, för den staden är ju tillräckligt åtskild från Stockholm för att undgå dess inflytande.» Ett oväntat, smått förbluffande svar, tyckte jag då. Senare förstod jag vad han menade. Aalto såg tydligen konst som ett relationellt fenomen. Tänker mej en pulserande triangel, med människor, konst och miljö i de tre hörnen. Och endast om triangelns hörn eller vändpunkter är i trim, laddade, fungerar den kommunikativa strömmen.

Vi gick aldrig in på stadsplanering, vilket var ett alltför vidlyftigt ämne för ett lågmält samtal, men snuddade $\mathrm{i}$ förbifarten vid några av ämnets gränsstolpar. Mötet mellan stad och land skulle vara direkt och omedelbart, utan den skräpzon, som vanligen omger storstäderna. En enkel synpunkt på avgasfrågan, som jag aldrig tänkt på, nämligen att en hårt trafikerad gata med hus endast på ena sidan har betydligt bättre luft än om gatans båda sidor är bebyggda. Det lät riktigt, men förgäves försökte jag föreställa mej, hur en stad med ensidiga gator skulle se ut. Men senare förstod jag. Aalto ansåg storstaden vara ett färdigskrivet kapitel och tänkte sig en ny slags stad utanför den gamlas hank och stör med odling, natur, bostäder och industrianläggningar i öppna förband - en blandning av stad och land.
Och i en sådan gles urban väv passade det med ensidigt bebyggda gator eller vägar.

Ofta under vårt långa samtal flikade han in något, som tydligen låg honom varmt om hjärtat. Han ville hellre rita bibliotek, auditorier, kulturcentra - allmännyttiga anläggningar - än privatbostäder och kommersiella byggnader.

Vi kom in på rumsgestaltning och han lyssnade intensivt på vad jag hade på hjärtat. Berättade om ett besök på ett stockholmssjukhus, där min svårt drabbade far låg intagen. Sjukrummet hade chockerat mej: de kala väggarna, de grova materialen, den vitlackerade sängen som stod utskjuten under ett glåmigt takljus. "Rena garagekänslan", utbrast jag. Då såg jag hur hans blick mörknade. Han stirrade ned i bordsskivan och mumlade för sig själv: «Det är inte bra, det är inte bra.»

Så fyllde han på våra glas igen (var det sherry eller whisky?) och jag tog upp tråden genom att fråga något som jag grunnat mycket på. Att skapa, eller enklare, att göra något nytt, kunde det ske med helt rationella medel? Var målet förutsebart eller oförutsebart - och om det senare kunde slutprodukten anas på något sätt? Men trasslade inte in mig i den tankeväven, utan lyckades formulera mig klart och utan omsvep: "Ni, arkitekt Aalto, som arbetat ett helt liv med arkitektur och allt vad därtill hör och använder er av skisser, modeller, försök och experiment, för att i mesta mån vara säker om utgången. Är då den färdiga byggnaden alltid precis som $\mathrm{ni}$ tänkt er?» - «Nej», och svaret var lika kort som frågan lång: "Det är alltid en surprise." På franska, som han gillade.

Värmen, det stimulerande fria samtalet, min nyväckta självkänsla, för att inte tala om det vi drack (sherry eller whisky?), 
70 gjorde kanske att jag spelade över och mina frågor blev alltför raka och okänsliga. T. ex. när det gällde hans funktionalistiska kolleger på kontinenten, Walter Gropius, Le Corbusier, Neutra m. fl. Då blev svaren korta och skämtsamma, karikerande till innehållet. Le Corbusier var "en bra pojk», men obotlig mångsysslare. När han ritade hus, skulle han måla tavlor, när han målade tavlor, skulle han skulptera, skriva böcker, hålla tal eller bli textilkonstnär. Men den snabbskissen sa nog mer om Aalto än om hans schweiz-franske kollega. Alvar Aalto tog sitt yrke på största allvar, smälte samman med det. Det var som han var gjord i ett stycke.

Aaltos nästan självutplånande gästfrihet gjorde att jag alltför mycket kände mig som samtalets huvudperson, vilket verkade förvirrande och overkligt. Och jag fick anstränga mej för att hålla i sär våra olika roller.

Kanske han märkte min osäkerhet och ville visa var skåpet skulle stå - för plötsligt ser jag arkitekt Aalto sträcka på sig i stolen, rikta en blick von oben på mig och förkunna med tordönsstämma: "Madame Kennedy ringde igår.» Det kom så plötsligt och oväntat, att jag först inte förstod vilken madame det gällde - och när jag väl gjorde det, visste jag inte vad jag skulle svara. Han väntade tyst och såg på mej. Vad ville hon då? Jaså, verkligen. Hur kom det sig? Nej - till slut fick jag fram ett krystat: «Vad gällde då samtalet i fråga?» «Hon ville att jag tillsammans med några andra arkitekter skulle skapa ett monument över hennes make (John F Kennedy).» - "Och vad svarade ni då?» «Jag svarade nej!» dundrade han till.

Men endast två gånger under seansen anspelade han på sin internationella rykt- barhet. Andra gången var när shahen av Persiens tilltänkta museum kom på tal. Han beklagade sig, kanske något affekterat, över att man inte kunde kunde besöka persiska hovet ensam, eller med några kolleger på yrkets vägnar, utan att det krävdes en hel delegation. "Arton personer", sa han, om jag minns rätt. Höll då fram mina händer i en bärande gest och erbjöd mig att ansluta till karavanen om någon plats skulle visa sig vara vakant. Ett litet skämt som han viftade bort som en osynlig fluga.

Det hade nu blivit sent. Det var nästan mörkt i de högtsittande fönstren. Värden meddelade att vi tyvärr måste sluta vårt intressanta samtal - och jag insåg att jag dröjt kvar för länge - för familjens hembiträde, som var frikyrkligt, skulle på möte i Helsingfors. Vi gick ut till den sluttande tillfarten och han varnade mej för halkan. Själv hade han after-ski-boots med lameller i sulorna, vilka han nöjd visade mej.

Vi fick sällskap en bit och när vi kom till hållplatsen, pekade han på en vit byggnad med kraftfulla murar. "Det är Lars Sonck," sa han, "och hans arkitektur sätter jag mycket högre än Eliel Saarinens.» Sedan vek han av mot sin privata bostad "på en engelsk mils avstånd». Långsamt och tydligen i tankar gick den lille men rake mannen i väg - medan jag åkte in till mitt enkla rum på Frälsningsarméns Hotell. Sammanfattade vårt samtal i tio punkter, läste dem om och om igen, memorerade dem tills de borde sitta i ryggmärgen, varefter jag rev sönder lappen. Ville inte bli beroende, tappa distansen till Aaltos person och byggnader. Gärna följa Aalto i spåren, men helst litet vid sidan om, så jag kunde se vart spåren ledde. 


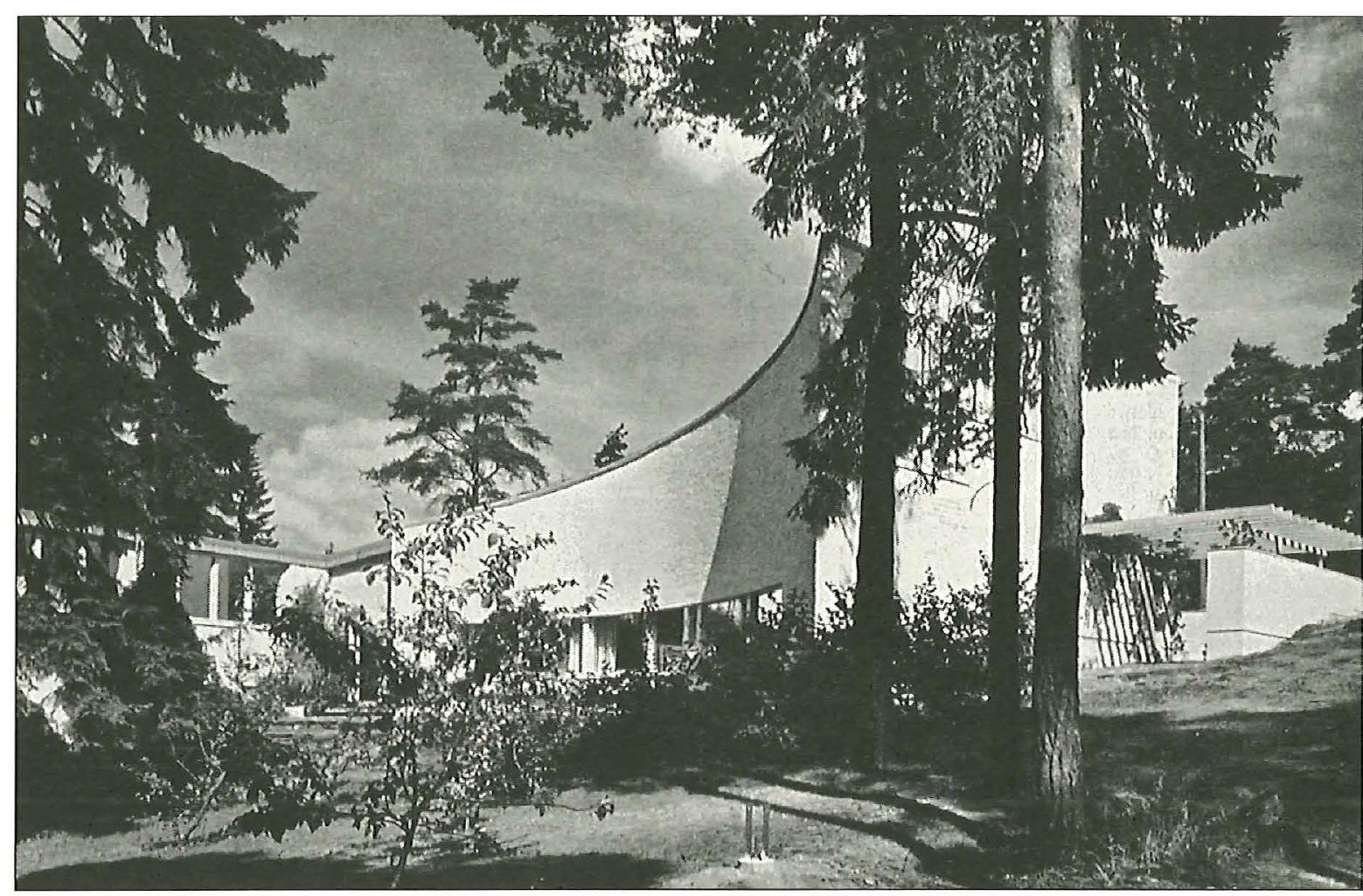

Aaltos ateljébyggnad i Munknäs, Helsingfors.

\section{ETT NYTT MÖTE}

Andra gången jag fick träffa arkitekt Aalto var i baren på Strand hotell i Stockholm. Han var då så ivrig och upptänd av sina tankar, att han började tala, innan han satte sig på stolen. Han berättade att han kom från Aalborg i Danmark, där hans konstmuseum var under uppförande. «Belysningen var inte bra,» utbrast han och jag frågade följsamt om tavlorna inte var bra belysta. "Jo, tavlorna var nog bra belysta, men människorna var det inte. De var för mycket i skuggan.»

Igen ställdes allt på huvudet och jag kände som om något frigjort sig från den invanda verkligheten och seglat upp i en okänd rymd. Men, menade han vad han sa, eller var den dåliga belysningen bara en förevändning för s. k. fritt formskapande? Jag var övertygad om att han menade allvar, för när jag frågade vad han tänkte göra åt det, svarade han kort: «Dom får göra om alltihop." Museet var ju som sagt under uppförande.

Och som en förklaring dök den relationella triangeln upp igen och viftade med sina tre hörn: konst, publik, miljö. Och alla polerna skulle vara maximalt laddade om det - kort sagt - skulle bli konst(upplevelse) av det hela. Om 'publikhörnet' släpade efter, bröts strömmen och kretsloppet kom inte igång. Alvar Aaltos relationella konstsyn har framtiden för sig (och jag instämmer helhjärtat i den).

Han berättade en lustig historia om en konstdoktor i Wien, där han nyss varit, som hade bett honom om en definition av «vad god arkitektur är». Aalto hade då tagit upp en liten tändsticksask ur fickan (vilket han gjorde nu också) och förklarat att god arkitektur skall vara som denna tändsticksask, ha bra proportioner, dörrar och fönster skall passa in i fasaden, precis som bilden passar på askens sida. Och stryker man en tändsticka mot plånet (vil- 
72 ket han gjorde) så flammar det till. Får jag skriva det, hade doktorn frågat, och Aalto hade gett sitt tillstånd. Han skrattade och såg plirande på mej - och jag kände mej väl lika dum som österrikaren troligen känt sig.

Först i efterhand började det klarna och jag förstod meningen med skämtet. Alvar Aalto misstrodde - med all rätt - språkets förmåga att infånga vad De Stora Orden stod för. Vad är arkitektur, löd frågan och svaret blev att denna 'mjukvara' endast kan om- och inskrivas på metaforisk väg. Han använde ett skämtsamt, ironiskt bildspråk för att markera att orden ändå bara nådde halvvägs.

Aaltos practical joke på estetikens område hade alltså en allvarlig underton. Han uttryckte sig ofta halvt på allvar, halvt på lek. För att ge svängrum åt fantasin och hålla alla dörrar öppna.

\section{SYNPUNKTER PA ALVAR AALTOS MUSEER}

Aaltos stora verk (ca 350 byggnader och projekt) uppvisar ett fåtal, men rikt varierade, formmotiv, som korsas och smälter samman, för att så 'koagulera' till ständigt nya motiv och rytmer, i vilka ursprunget eller förlagan dock alltid är kännbar. Ett slags naturlig variationsrikedom. Nya grenar på ett och samma träd. I Göran Schildts förteckning kan man räkna till totalt 15 museiprojekt, varav endast fyra blev förverkligade - Aalborgs konstmuseum, Finlands paviljong för venedigbiennalen samt två specialmuseer för Jyväskylä, där Aalto fått sin skolutbildning. En tillfällig utställning och ett museum är två näraliggande uppgifter och mycket av vad som kan sägas om hans vandringsutställningar gäller också museerna, t. ex. struktureringen av innehållet i s. k. kvanta, klart urskiljbara, ofta olikstora delar. Eftersom museet är en större och mer komplicerad uppgift än vandringsutställningen, statisk till naturen jämfört med den tillfälliga exposén, som skiftar $s$. a. s. både i tid och rum, så krävs det en utveckling av de rumsliga och pedagogiska idéerna, såväl som en del nya grepp. Jag har valt att skildra fem projekt och en färdig byggnad - Aalborg-museet. De har ett rumsligt motiv gemensamt: echelonen eller avtrappningen, och genom att följa det får man en tämligen fullständig bild av Aaltos museifilosofi. Precis som vi i "Aalto på Moderna museet» (vilken jag behandlar i en kommande artikel) får ut det mesta av hans inställning till tillfälliga utställningar, kan vi i ett enda museiförslag utläsa det väsentliga $\mathrm{i}$ hans syn på museet. Museet $\mathrm{i}$ fråga är Tallinns konstmuseum, 1937, rättare sagt ett ej utfört förslag i tävlan med bl. a. Ragnar Östberg. Museets storlek och sammansättning är ungefär desamma som ett svenskt länsmuseums.

Aaltos perspektivteckning till ingångshallen är som en öppen bok och med arkitektens koncisa förklaring är det mesta sagt: «Mitthallen, det förenande elementet, är ett motiv med småningom stigande skala, varvid var och en av de olika höga avdelningarna făr sin lämpliga höjd. Till höger bilda dörrarna till avdelningarna och framskjutande väggstycken tillsammans med trappan ett slags spaljé, sålunda att museets inre uppdelning genast står klar för besökaren".

Vilken suverän beskrivning! Interiören fattas med ett enda grepp!

Alltså. De överlappande, överkragande eller varandra överskjutande väggstyckena 


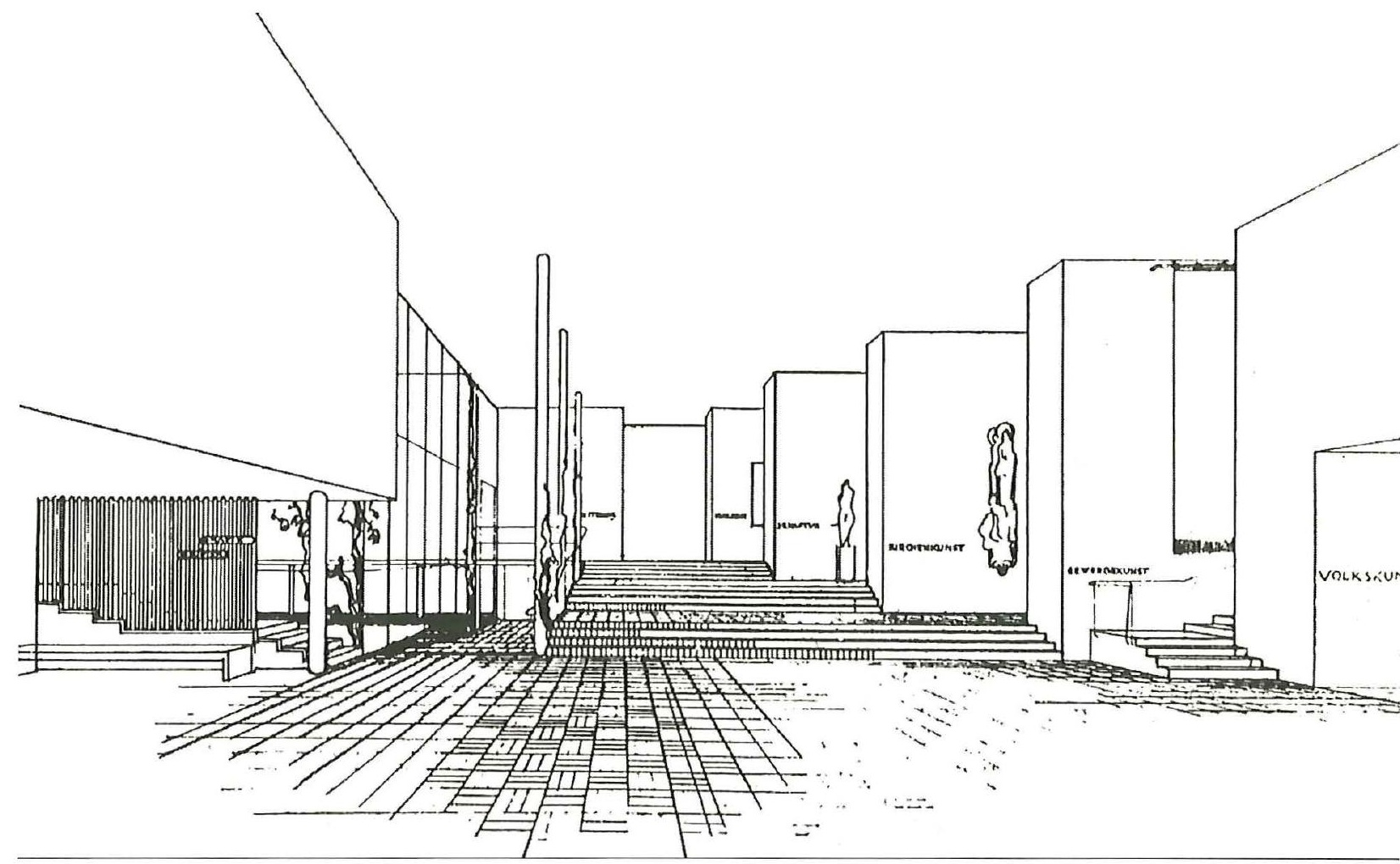

Entréhallen till museet $i$ Tallinn, projekt 1934.

t. h. på bilden leder in till de olika avdelningarna, vilkas respektive innehåll annonseras genom olika provbitar - ett kyrkligt konstverk, en skulptur, en målning - och eftersom golvet stiger får avdelningarna successivt lägre $\mathrm{i}$ tak och visar det sig - de är olika i allt, rumsform, proportioner, ljusförhållanden etc. Detta för att uppnå maximal anpassning till de olika konstslagens krav. Echelonmotivet, dvs. avtrappningen, som jag vill kalla det, för också med sig att hallen, som avdelningarna s. a. s. sällskapar med, smalnar mot fonden $\mathrm{i}$ en kompensatorisk minskning. Avtrappningen, som vi skall följa, är fördelaktig på fyra sätt:

1. Besökaren avläser genast på tröskeln museets innehåll. Med en enda blick står det klart för honom.

2. Valfrihet. Besökaren kan välja den avdelning eller det ämne han önskar se och gå rakt på mål, utan att behöva leta sig fram genom museet.

3. Ingen avdelning behöver vara genomgångsrum och kan därför vid behov avskiljas utan att besöksverksamheten därmed blir lidande.

4. Man går från en avdelning till en annan via hallen - men hela museets innehåll kan ses i ett svep genom den 'visitor's path' som letar sig fram tvärs avdelningarna - i utställningsutrymmenas mitt.

Tallinn-museets hall med dess vägledande avtrappning och ljusa luftighet kallar jag 'Alvar Aaltos öppna fördelardosa'.

Längst bort efter några trappsteg kommer man till ett tämligen smalt galleri, som, pelarburet, vinklar sig kring en öppen skulpturgård med grönska och vatten. Avsedd för tillfälliga utställningar. Aalto väljer mellan två olika typer av målningsgallerier. Smala korridorsalar - med överljus - närmast med hänsyn blott till långväggarna, samt «bredare rum» med smidigare användbarhet och möjlighet att anordna s. k. deltaväggar. Han väljer den bredare typen, därför att den är mer ekonomisk, mångsidigare användbar och gör att man kan betrakta målningarna från 
74 flera punkter och på olika avstånd. Bredden gör att man kan använda deltaskärmar, vilka av ritningarna att döma ser ut att vara samma sak, fast bastantare, som de halvhöga skärmar vi ser i hans tillfälliga utställningar och som också de ger en koreografisk frihet i rummet. För att ge gott ljus såväl åt väggarna som de fritt vinklade skärmarna, krävs ett speciellt belysningssystem - systematiskt placerade genom taket gående cylinderformiga stympade koner, varvid belysningen praktiskt taget uteslutande förmedlas av från de koniska ytorna återkastat indirekt dags- ljus. Alltså enbart reflekterat dagsljus, delat, spritt och finfördelat till ett fluidum i rumskuben, så att alla ytor, oavsett läge och riktning, får samma fina ljus. "Konisk reflektion» - något som Aalto först praktiserade i sitt Viborg-bibliotek (1931).

Avtrappningen - deltarytmen - konisk reflektion, är tre viktiga delar av Aaltos museiteori. Hur de utvecklas genom ömsesidig påverkan kommer att framgå av det följande.

Museet $i$ Tallinn, projekt 1934. Foto av modellen.

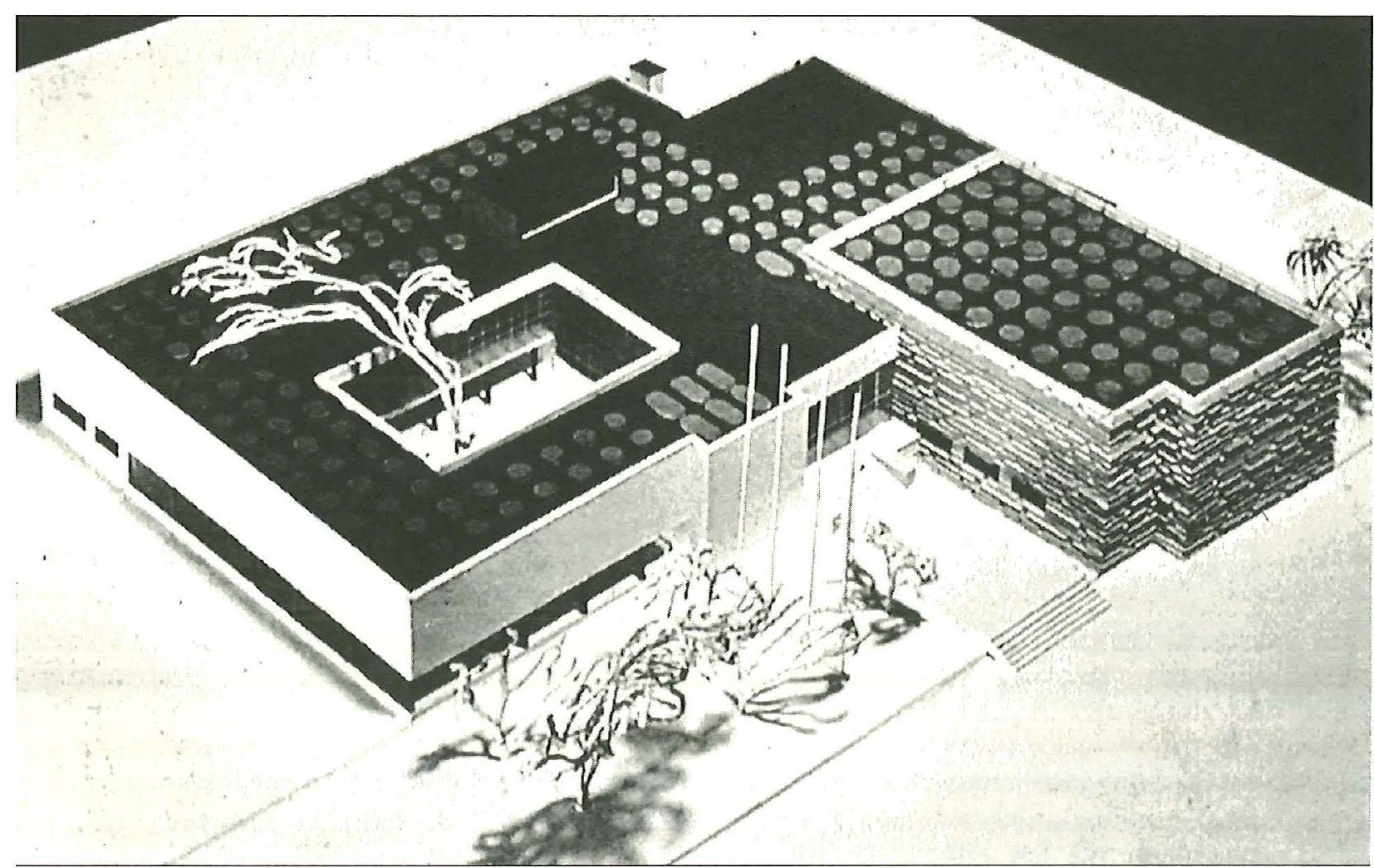




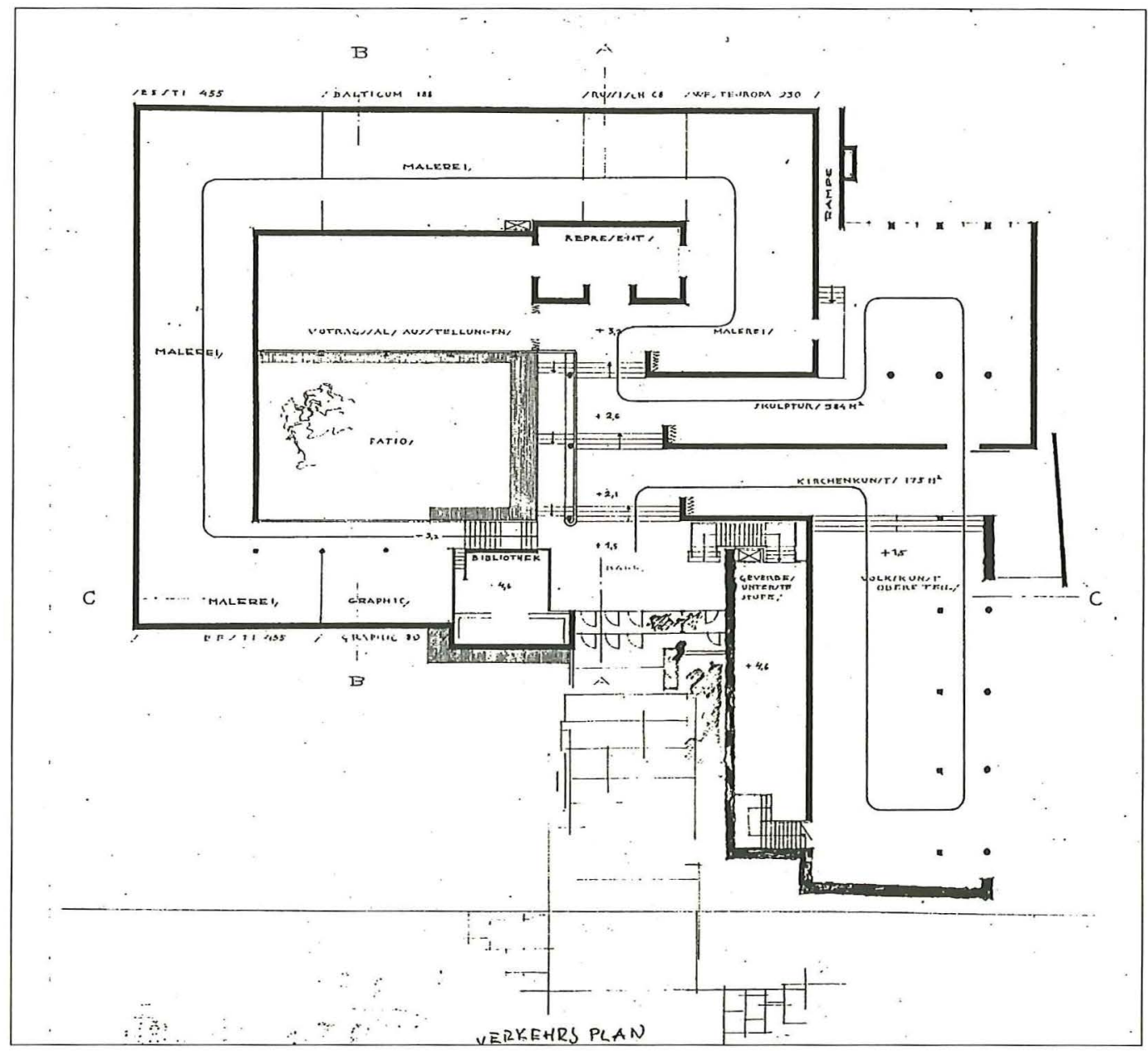

Plan, museet i Tallinn, projekt 1934.

\section{AVESTA-PROJEKTET}

Troligen 1944 presenterade Alvar Aalto för Axel Ax:son Johnsons räkning ett forskningsinstitut som skulle ligga på en slänt söder om Johnson-staden Avesta. Projektet blev till ingen del realiserat. Bland de många projekterade byggnaderna finns två mindre museer, det ena för sjö- fart, det andra för bergsindustri. De är tvillingar, tämligen lika såväl till storlek som plandisposition. Troligen skulle de skildra Johnson-koncernens utveckling på dessa två områden. Originalritningarna saknas enligt Schildt, det reproducerade materialet är magert och bristfälligt, men trots det får man en klar uppfattning om hur Aalto tänkt sig de två byggnaderna. 
Gösta SALÉN
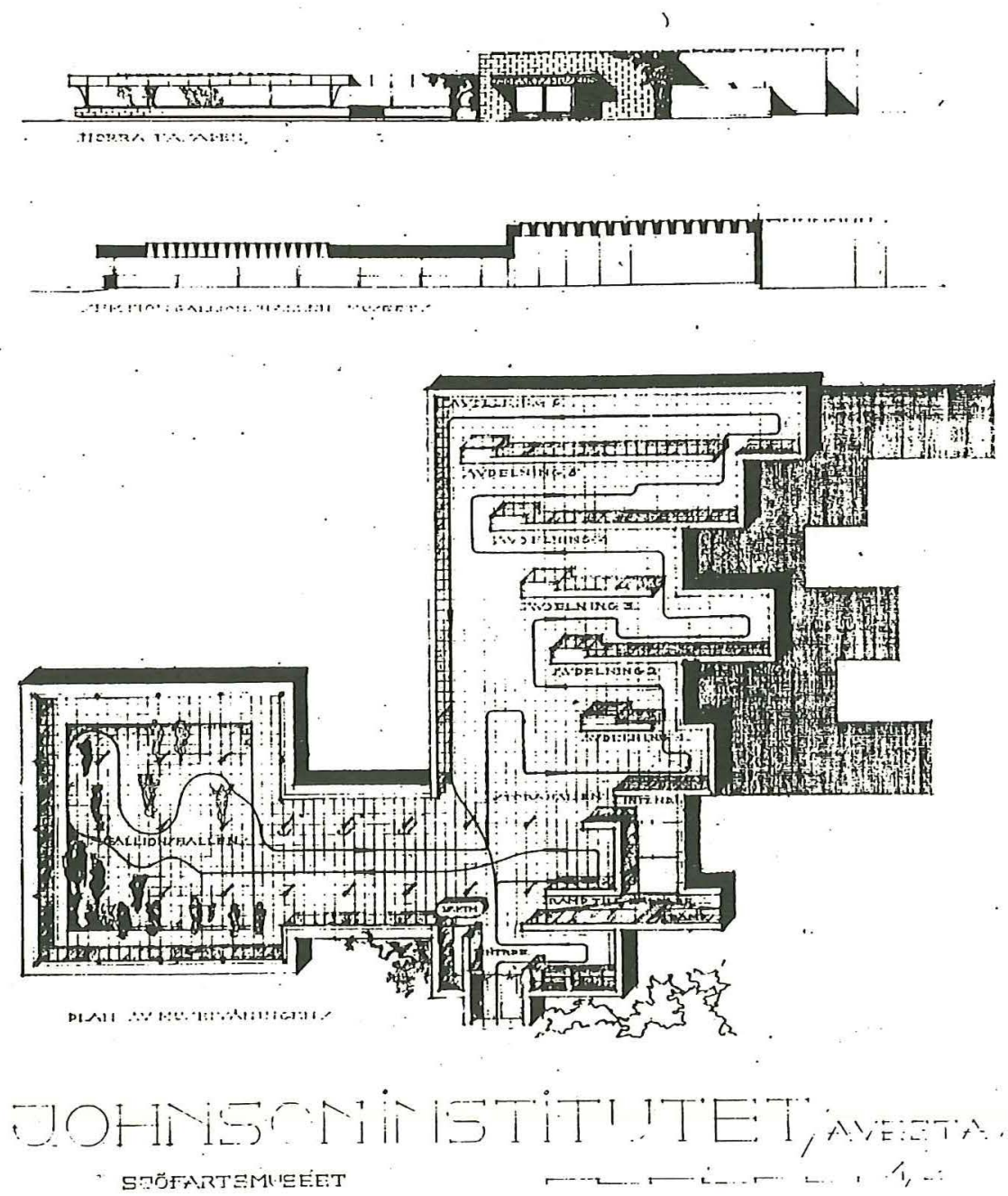
Återigen möter vi avtrappningen, echelon-motivet, och den sidoställda, avsmalnande foajén. Tänker man sig att man kom in i sjöfartsmuseet (längs med, intill grönskan) skulle man haft samma entrévy som i Tallinn. Enda skillnaden tycks vara att väggstyckena inte förannonserar genom att visa provbitar, troligen beroende på att här - i motsats till det omfångsrika Tallinn-museet - innehållet är homogent, endast sjöfart.

Planen avslöjar emellertid att avtrappningen här är något annat, dess funktion skiljer sig från den i Tallinn. Väggstyckenas mellanrum, eller entrégångarna, har förbundits vinkelrätt med varandra till ett löpande galleri, en slinga som vidgar sig mot fonden. I Tallinn var det ju fråga om gångar som ledde till samlingarna, här rymmer de samlingarna, kunde man säga. De nämnda deltaskärmarna med deras koreografiska frihet kan påminna om ett floddeltas högst varierande förgrening. Här i sjöfarts- och bergsmuseerna frammanar avtrappningen en annan naturens förebild, nämligen meandern, uppkallad efter en flod i Mindre Asien, som under motstånd banar sig väg med sakta vindlande förlopp. Aalto ger något av naturens variation och nyansering åt detta motiv. Slingorna når olika långt ut åt sidan, ansluter till väggen, eller lämnar en passage fri. En meanderslinga? Ja, men med pyramidal ökning och den ena sidan öppen mot foajén. Alltså. Avtrappningen och deltaskärmarna kan sägas ha gått upp i varandra, så att en ny rumsformation har uppkommit. Även den tredje ingrediensen har kommit med i fusionen, för över hela museilokalen lyser de koniska takfönstrens mångfaldiga solar. I Tallinn fick foajén sitt ljus från gården. När avtrappningen förvandlades från entréer till gallerier perforerades taket av tättsittande gluggar med konisk reflektion, som ger en «heltändning" av rumskuben.

Museet ger också ett intressant och mycket extremt exempel på den ljusanpassning, som vi noterade redan i Tallinns olika avdelningar. Paviljongen som skjuter ut till vänster var avsedd för en samling galjonsfigurer som Axel Ax:son Johnson fătt (köp eller lån?) från Danmark, som tack för ekonomisk hjälp under den tyska ockupationen. Aalto eftersträvade tydligen att återskapa något av det starka och skiftande ljus som omspolade dessa märkliga skulpturer till havs. Därför löste han upp det lilla annexet helt i glas. Glasväggar över låga bröstningar och få stadgande spröjsar samt ett tak fyllt med ovanligt djupa och tättsittande gluggar.

Men trots denna arkitektoniska striptease - f. ö. högst ovanlig hos Aalto - ansåg han tydligen inte ljusflödet tillräckligt. Skulpturerna verkade inte tillräckligt sjögående. För i ett (troligen senare) förslag avstår han, vad jag förstår, från paviljongen och flyttar helt sonika galjonsbilderna utomhus. Förvandlar dem till karyatider som gemensamt bär ett skärmtak över en bassäng mitt på det tilltänkta forskningsinstitutets torg.

Bergsmuseet är en tvilling (dock ej enäggstvilling) till sjöfartsmuseet. Samma meanderslinga under samma koniska belysning - «det ljus som människan så att säga simmar i», skrev Aalto vid den här tiden. 


\section{KONSTMUSEET I BAGDAD}

Kulmen och slutpunkten på avtrappningens utveckling nås med det 1957 ritade konstmuseet i Bagdad. Kung Feisal hade för sin huvudstads räkning planerat ett den moderna arkitekturens trekungamöte. Frank Lloyd Wright skulle sålunda svara för en kombinerad teater- och operabyggnad. Le Corbusier hade fătt i uppdrag att rita ett stadion och sportinstitut. Alvar Aalto slutligen var ombedd att gestalta sta- dens nya konstmuseum, vilket bl. a. skulle innehålla den stora Gulbenkian-samlingen som nu finns i Lissabon. Detta modernistiska uppbåd kom emellertid av sig, när kung Feisal störtades 1958, året efter det att Aaltos planer var färdiga.

Museet i Bagdad torde ha blivit ett av arkitektens rytmiskt sett mest fulländade och harmoniska skapelser - om man kan döma av en plan och en elevation i Schildts förteckning. Liksom i föregående fall ägnar jag mig endast åt utställningsutrymmena.

Plan för konstmuseum i Bagdad, projekt 1968.

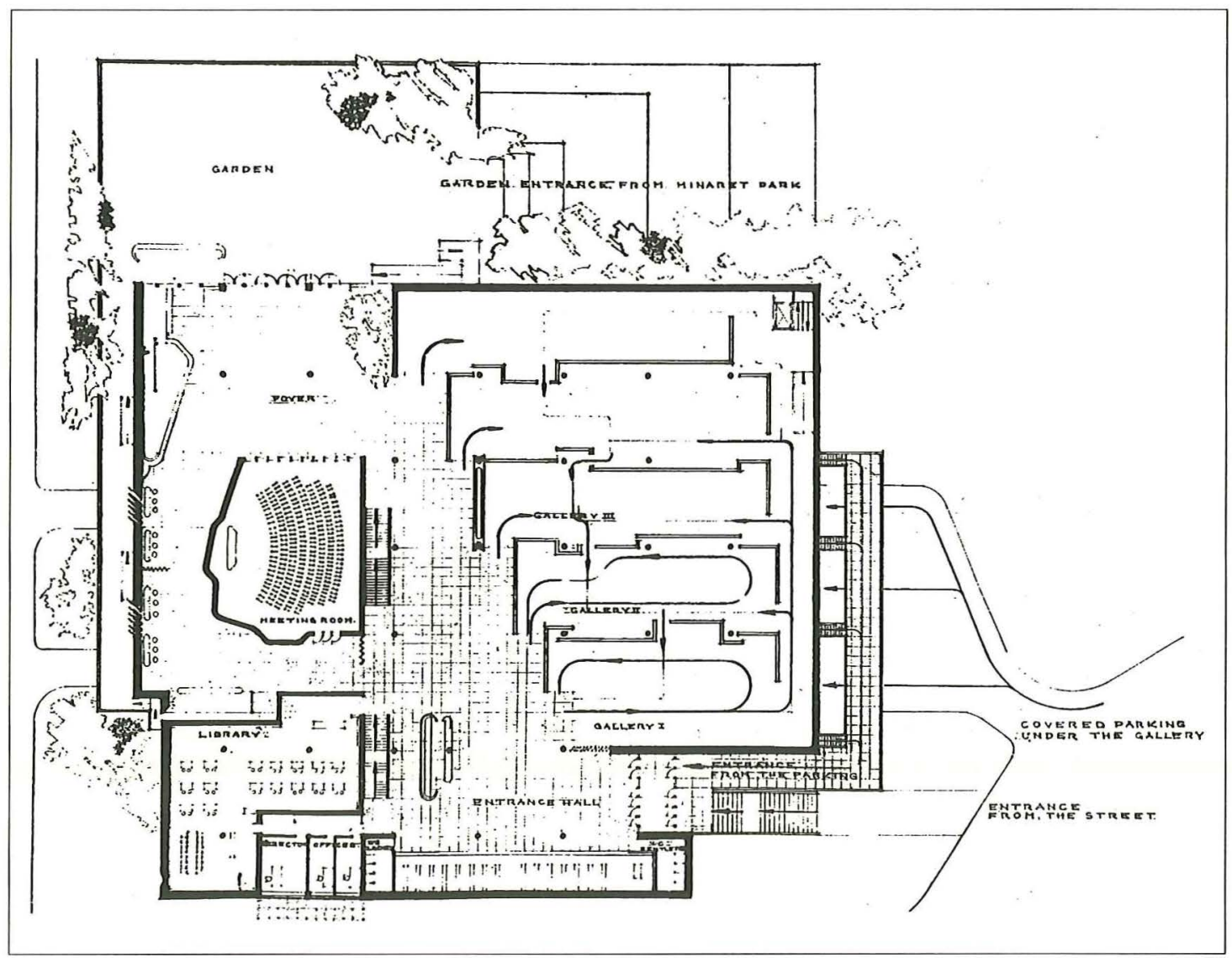




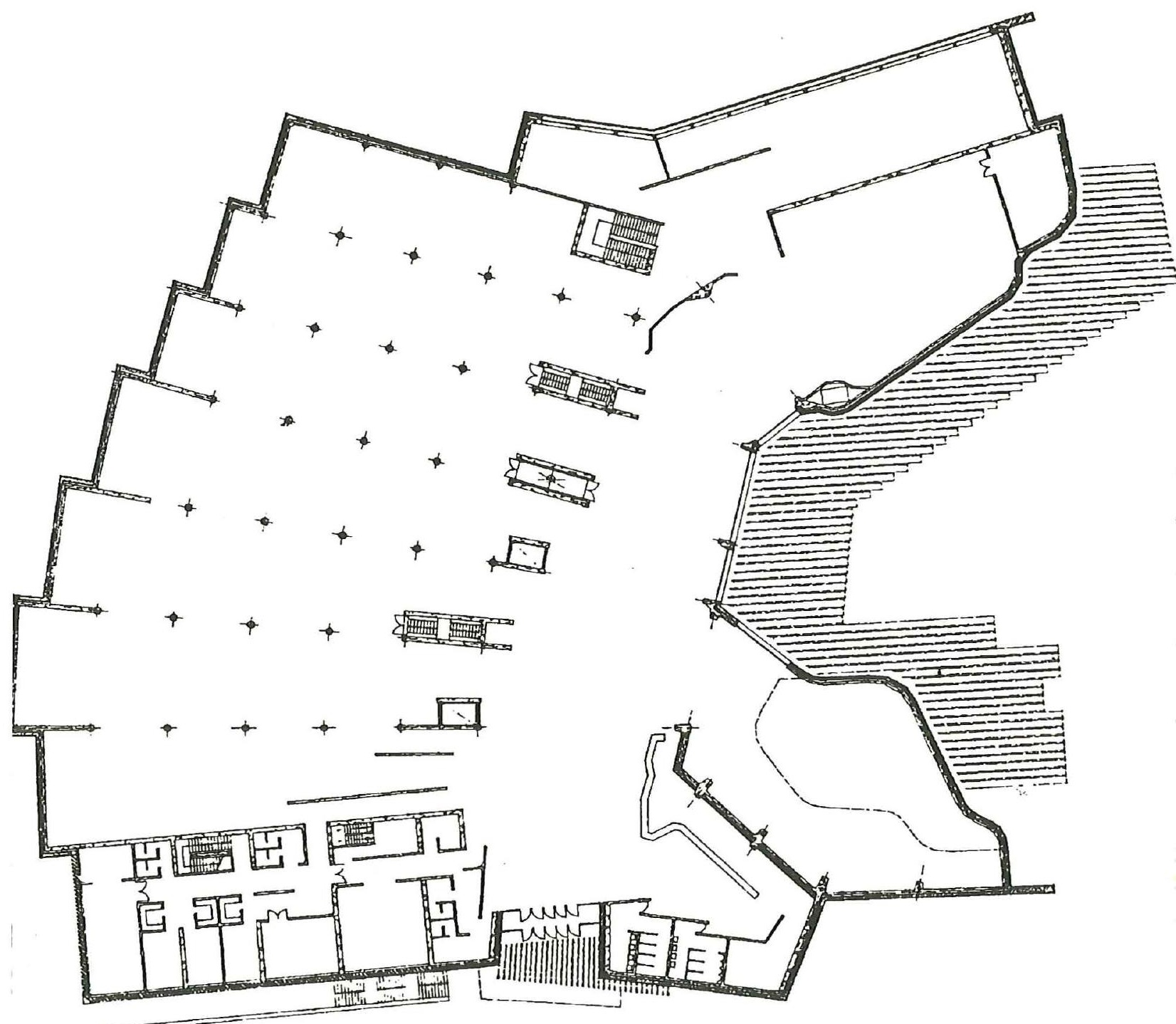

Plan for konstmuseum i Shiraz, Persien. Projekt 1969.

Återigen - och för sista gången i Aaltos verk? - möter vi avtrappningsmotivet i förband med den avsmalnande foajén som medger valfri in- och utgång. Men en väsentlig förändring har inträffat. Meanderslingan tycks vara i upplösning. Gallerierna är ej längre vinkelrätt förbundna utan bildar isolerade salar, som man tar sig in i från båda sidorna, även från höger via en smal gång längs museets yttervägg. Slingans sidor (meanderns stränder) har luckrats upp, veckats, förskjutits, fragmenterats i så hög grad att det bildats hål och smärre passager som tillåter såväl genomblickar som genomgång. Labyrinten läcker! Tvärs stapeln med gallerier letar sig en 'visitor's path', som ger en överblick av innehållet. Rumsligheten artikuleras, varieras, differentieras så att den plastiskt anpassas efter innehållet varje utställt föremål tilldelas på så sätt sitt speciella livsrum och besökaren bjuds på en visuell blandkost som stimulerar och förnyar seendet. Något av den koreografiska frihet som vi kan se i de tillfälliga utställningarna, t. ex. i Ateneum i Helsing- 
80 fors, har kommit tillbaka. Deltaskärmarnas deltarytm, men nu i mer bunden och systematisk form. Synkoperad deltarytm, kallar jag det.

Alvar Aaltos avtrappning, slinga, meander, labyrint eller vad man vill kalla motivet $\mathrm{i}$ fråga har ju mycket som talar för sig, men väcker troligen såväl frågor som kritik bland experter. En besökare kan ju bara röra sig på ett enda sätt, när han tar del av materialet. Han tvingas in i en enda fåra. Det kan vara berättigat att tala om en 'riktad besökare'?

Museislingans bundna rytm, den geometriskt-spatiala planfiguren är ett oväntat och ovanligt inslag i arkitektens verk. Varför? Vad avsåg Aalto med detta - trots varianterna - rätt stereotypa arrangemang? Jag försöker ge några svar på frågan i sista avsnittet, men först ett museum som, i motsats till de nämnda, inte stannade på papperet, utan kom att se dagens ljus.

Det märkliga konstmuseet i Aalborg som stod färdigt 1972, efter ett fullständigt och detaljerat förslag redan 1952. Nordjyllands konstmuseum.

\section{NORDJYLLANDS KONSTMUSEUM}

Museets grundplan är en något långsträckt kvadrat, om man så kan säga, med en likaledes formad mittsal, vriden 90 grader mot planens längdaxel. Ljus, hög, luftig och tekniskt välutrustad är den ett exempel på de konstens allrum som uppfördes på 1960- och 70-talen, avsett för alla tänkbara - och otänkbara - konstevenemang. De fyra höga lanterninerna skjuter upp över den envåniga byggnadskroppen och ger den en pyramidal resning. Runt denna ljusa kärna (även auditorium) ligger rummen och utrymmena för konstsamlingen, övervägande dansk konst från guldåldern (1829-40) fram till yngsta generationen, en donation av brännvinsfabrikören Harald Jensen och inköp från tandtekniker Kresten Krestensen - vilket föranledde signaturen Jolo, att i sin rapport från invigningen konstatera: «brännvin och dåliga tänder befordrar också kulturen».

Det är anmärkningsvärt att samlingens olika riktningar och epoker tilldelats rum av olika slag och - framför allt - med skiftande belysning. Den föreställande konsten - t. o. m. impressionismen - återfinns i sju kammarliknande rum med dagsljus från stora fönster mot en sluttning klädd med vacker skog (museet ligger f. ö. i ett tidigare grustag). Sekelskifteskonsten i byggnadens hörn, ryms i ett tredelat fönsterlöst utrymme, belyst från tre taklanterniner. Dagsljusbelysningen - antar jag - tar fram djupet och detaljerna i de perspektiviska bilderna, medan belysningen enbart von oben lyfter fram ytvärdena hos den gryende modernismen, färg, form, material och faktur. 1900-talets olika riktningar breder sedan ut sig i rumslig frihet inom de vinklade deltaskärmarnas hägn. Men märk och observera, att den koniska belysning som erfordrades för koreografisk frihet förekommer varken här eller någon annanstans i museet! I dess ställe sträcker sig långa, rektangulära lanterniner genom museet ända fram till mittsalens ljusa rymd. I den färdiga byggnaden har deltaskärmarnas förgreningar ersatts med stora, lösa väggstycken placerade mellan de bärande pelarna, så det bildas fem stycken basilikala skepp, vilka i 
önskvärd grad kan slutas mot varandra eller öppnas helt till en pelarhall av moskétyp. Denna luftiga rumslighet möter vi i ett mycket raffinerat utförande i planerna för museet i Shiraz (som ej kom att byg- gas) - skeppen vrids, förskjuts, ökar i höjd mot byggnadens mitt.

Lanterninerna i Aalborg består av nedhängande väggstycken (takstycken?) i skeppens längdaxlar. Sidorna är olika konkavt

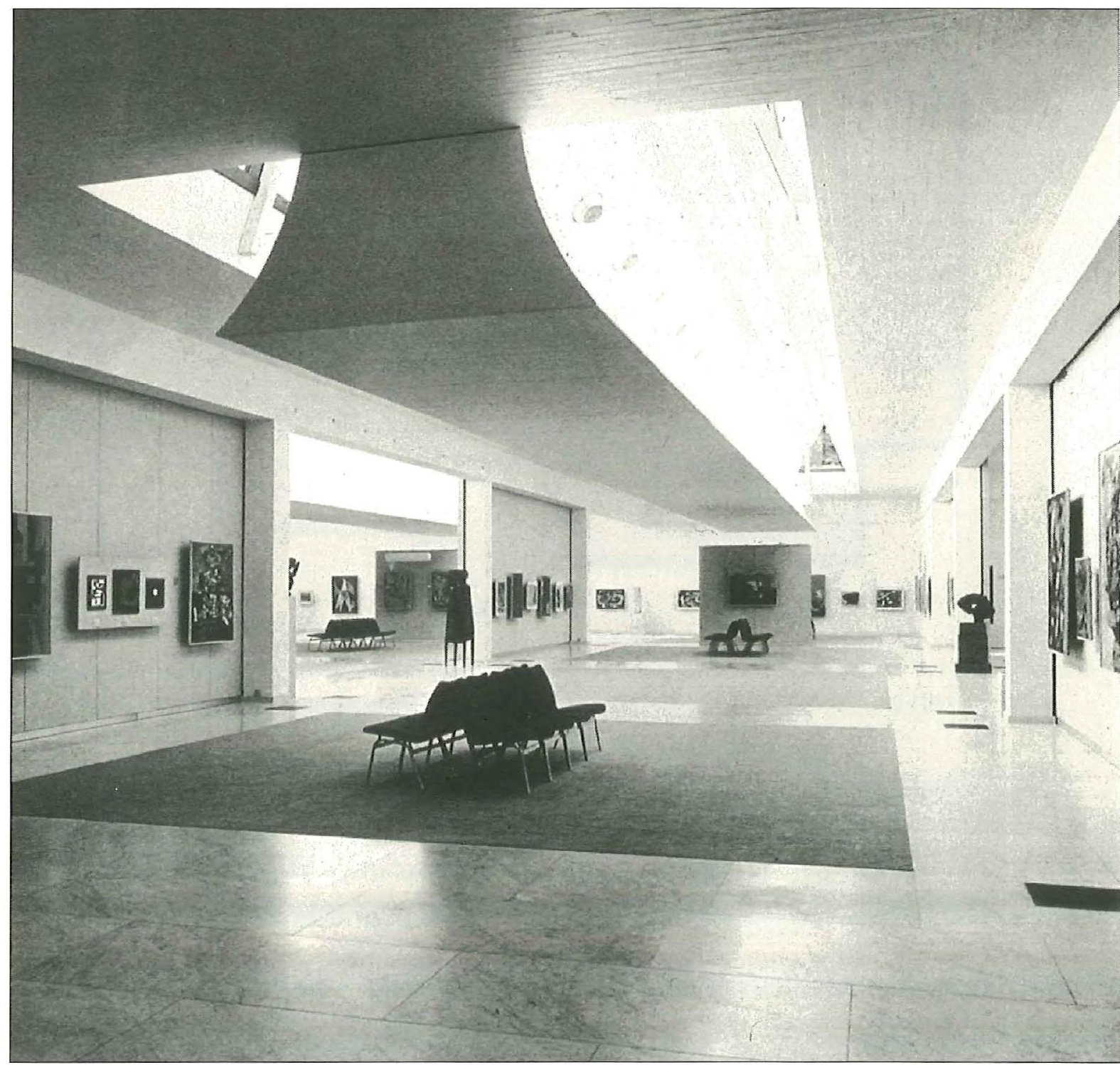




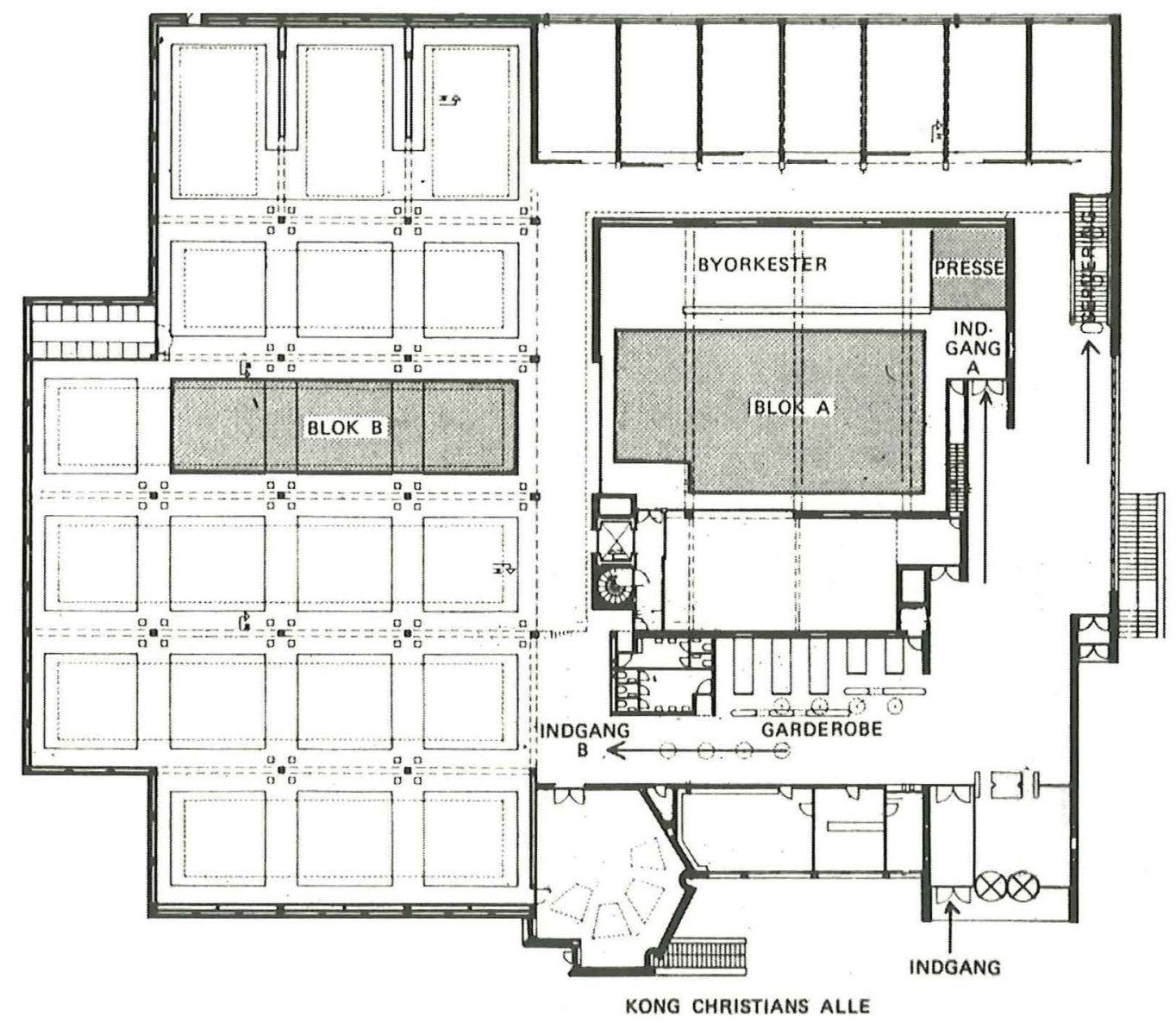

Nordjyllands Konstmuseum, Aalborg, Danmark. Plan med sittarrangemanget frän invigningen.

svängda, beroende på väderstrecken. De reflekterar dagsljuset paraboliskt, huvudsakligen mot sidoväggarna och konstverken får däremot ett skugglöst ljus, utan blänk och reflexer. Lamporna har placerats i dagsljusets reflexpunkter. Vilket gör att dagsljus och kvällsljus blir nästan lika. Endast en skiftning i kulören märks när lamporna tänds.

Det verkar som om denna nya belys- ningsteknik, som Aalto här lanserar, har lett fram till en mer regelbunden och konventionell rumsbildning. Det är ju fråga om vanliga museisalar fast längre och smalare. Aaltos labyrint har slutligen rätat ut sig.

Avtrappningen, vart tog den då vägen? Den finns, men har tilldelats en annan, mer sidoordnad roll - blivit entrégångar igen, som i Tallin. Stora salens vägg mot 
foajén har stegvis skjutits in, avtrappats, så det bildas två klart åtskilda entréer, den första till skulptursalen och den andra till mittsalen. Aalto tycks inte ha varit vän av folksamlingar och förflyttning i grupp. Därför gestaltar han planen så, att besökaren redan i entrén urskiljer olika stråk eller leder att vandra, mål för blicken, spridda sidledes och med olika djup i rummet. Förutom de två nämnda gångarna urskiljer man ett stråk som leder längst bort, där en belyst vägg pekar mot konstens domäner. En tydlig balustrad annonserar en trappa på halvdistans, vilken leder ned till de lägre regionerna och en fritrappa, alldeles intill entrén löper längs fasaden och har som enda uppgift att ta besökaren ned till museets utställningspark.

Aalto trafikseparerar således gångtrafiken! Han bjuder på flera vägar i stället för en. Enskild förflyttning med målet hela tiden i sikte - i stället för att trängas i grupp och inte se vart man kommer.

\section{SLUTORD OM AVTRAPPNINGEN}

Slutligen några synpunkter på avtrappningen, echelon-motivet. Trots att besökaren med en enda blick kan välja den avdelning han vill se och avbryta studiet närhelst han önskar genom att ta några få steg ut i foajén - måste han ändå följa den relativt trånga slingan när han tar det utställda i betraktande. Man talar om riktad utställning. Är det inte som tidigare sagts berättigat att här tala om en riktad åskådare? I Aaltos labyrintiska arrangemang är åskådaren tvungen att följa den föreskrivna routen, hålla i de ariadnetrådar som finns markerade på planen. Detta är väl att bokstavligen följa Alvar Aalto i spåren!
Den slingrande labyrinten är tydligen avsedd för mindre besöksgrupper. Hur klarar den en bred och strid publikström? Frågan är - om jag förstått arkitekten rätt - ovidkommande. Hans åsikt är att ett museibesök, särskilt om det gäller konst, måste vara något av en enskild angelägenhet som kräver ett visst mått av ensamhet och ostörd koncentration. Att se i grupp gör det svårare att förstå och uppleva det man ser, tycks han mena. I det perspektivet blir ju Aaltos 'urvalsslinga' den rätta lösningen.

Slingan, som jag nu förenklat kallar den, börjar smått och slutar stort. Jag kan tänka mej tre förklaringar till detta accelererande. I Johnsons Sjöfartsmuseum, liksom hans Bergsmuseum, skildras ett växande skeende, utvecklingen från en blygsam början till en stor koncern. Den ökande rumsformen passar därför innehållet. Men vad som ligger bakom slingans tillväxt i Bagdad-museet, kan jag inte föreställa mej, eftersom jag saknar uppgifter om detta museums faktiska innehåll.

Kanske Aalto hyste den åsikten att det är pedagogiskt riktigt att förse det utställda med en kort introduktion, en synoptisk sammanfattning som sätter besökaren i stånd att tillägna sig innehållet i successivt allt längre och mer detaljerade avsnitt? I så fall är det växande utrymmet motiverat. Eller, för att ta en närliggande synpunkt, fanns det ett psykologiskt motiv bakom «det växande museet»? Innehållet i en utställning är ju ofta för besökaren något nytt och okänt. Det kan därför vara befogat att ta det lugnt i början, en 'förvärmningsfas', varefter man kan tillgodogöra sig innehållet i stigande takt och i ökad mängd. Det verkar förhålla sig så, när man vandrar genom en utställning, att ju mer 
man ser och förstår, desto mer vill man se och förstå. Aptiten växer medan man äter.

Det ligger troligen något i dessa blandade synpunkter, men först när man har tillgång till detaljerad beskrivning av respektive museers innehåll och dispositionsplaner, kan man helt fatta Aaltos avsikt med det labyrintiska rummet. Några sådana avslöjanden har jag inte stött på i Aaltolitteraturen, inte heller $\mathrm{i}$ arkitektens egna skrifter. Kanske finns det relevant material i Aalto-arkiven? Att leta i gömmorna. Det vore en intressant uppgift väl värd ett försök.

\section{SUMMARY}

On the track of Alvar Aalto

The first part of the paper describes two encounters with the famous architect. The first one, which afforded the opportunity for a long conversation, occurred in 1965 when the author went to Helsinki to acquire pictures for an architectural magazine. The other was the occasion of a shorter exchange and took place some years later when Alvar Aalto passed through Stockholm on his way from Aalborg, where his art museum was being built. The second part of the paper offers a comprehensive analysis of some of Aalto's art museum projects based on hints which Aalto dropped in the conversations mentioned. Four museum projects that were never realized are scrutinized - the art museum for Tallin, Estonia, the maritime museum sketched for Avesta, Sweden, the art museums for Bagdad, Iraq, and Shiraz, Iran - as well as the only one which was built, the art museum in Aalborg, Denmark. Three basic themes seen as being essential to Aalto's ideas about museums, are discerned. The first is the 'echelon' motif which opens up the museum to the visitor and is combined with various types of pathways to direct the visitor through an exhibition or collection. The second comprises the free-standing 'delta' panels and the third the lighting based on a large number of conically shaped lamps perforating the ceiling. Together these elements produce the specific spatial experience necessary to load the relational triangle of visitor, art and space with the desired tension.

Gösta Salén är arkitekt, konsthistoriker och utställningsproducent. I den sistnämnda egenskapen har han fram till sin pensionering for nagra àr sedan varit knuten till Riksutställningar, Stockholm. Adr: Drottningholmsvägen 76, S-112 42 Stockholm 